\title{
Academic Racism
}

\section{William L. Howard}

... to be choked with hate

May well be of all evil chances chief.

... An intellectual hatred is the worst,

So let her think opinions are accursed.

-William Butler Yeats, “A Prayer for My Daughter”

Yeats might not comprehend the details of American politics today, but he would certainly recognize the political frame of mind. He witnessed the Easter Uprising and Irish "troubles" of his own time. He was in love with a political activist and thought her susceptibility to political hatred a tragic waste. However different our politics from his, he would recognize that the fuel that drives each is ideological hatred.

The French philosopher Jacques Ellul defines ideology as "the popularized sentimental degeneration of a political doctrine or worldview" and argues that it only dimly reflects what were once substantial principles. ${ }^{1}$ In the United States, words like "hate," "racism," and "white supremacy," routinely used by "the woke," are resuscitated and rebranded, but disembodied. That their referents have little resemblance to the referents of the same words in earlier times is called evidence of the acumen of the intellectual counterfeiters who redefine them. In fact, it is evidence that the ideology of the woke is "untouched" by reality, as Hannah Arendt described twentieth century totalitarianism. Ideology, she argued, "serves to emancipate thought from experience and reality."2

The newly branded version of "racism," for example, being far removed from actuality, begs for a qualifying modifier. It can be called "academic

1 Jacques Ellul, Jesus and Marx: From Gospel to Ideology (Eugene, OR: WIPF and Stock, 1988), 1, 4.

2 Hannah Arendt, "Ideology and Terror: A Novel Form of Government," in Orwell's Nineteen Eighty-Four: Text, Sources, and Criticism ed. Irving Howe, 2nd ed. (New York: Harcourt Brace Jovanovich, 1982), 415-

17. From Arendt, The Origins of Totalitarianism, 2nd ed. (World Publishing, 1958). 
racism," the object of a futile search by the intellectual class for conditions today that might make fighting racism heroic and relevant again. It is an ideology that is not only false but sinister. Unfortunately, ideological falsehoods are more likely to empower than invalidate, as Nazism and Communism proved. Likewise, academic racism has accumulated more power than its feeble rationale merits, and that power fuels the political enmity that threatens this country. The accusation of racism, with little evidence to back the charge up, is a weapon with the power to intimidate and deceive millions. The woke have flipped the script. They have employed their own racism to demean tens of millions of white people and consign them to a social perdition based on race and ethnic history.

Academic racism is an intellectualized and race-based ideology of hatred fostered and propagated in classrooms and newsrooms. This is not Bull Connor's racism. It is worse. Rather than transparent, unadorned, visceral hatred, it consists of a maze of theory that conceals visceral hatred under a veneer of intellectualism and enlightenment. Its object is to attain political power. Now that the woke have attained that power, they intend, with the leadership of the President of the United States, to institutionalize their own racism. The woke mind could be the subject of an engrossing psychiatric study of projection. Those who authorize themselves to accuse others of racism are the racists themselves.

These racists do not wear white hoods, police blue, or MAGA hats. They are college educated and conformed to an admixture of cultural Marxism and racial mythologies like critical race theory that have arisen from a desire to discredit Western culture. The farther away from past abuses such as slavery and Jim Crow this country moves, the farther from reality academic theorists' conceptions of racism become. To stoke its dying embers, they have developed a cleverly designed ideology that suppresses freedom of thought and justifies racially motivated malice. Their foot soldiers are too ignorant of the history of the twentieth century to know they are the ideological descendants of those responsible for the deaths of scores of millions of people.

The ideology of academic racism has been concocted in the laboratory of leftist ideologies: American universities. These increasingly totalitarian institutions have redefined the terms of antiracism, expanded its scope, and eliminated dissent. They devote themselves to preparing narrowly focused students to fight fervidly against those who purportedly benefit from the exercise of 
"hate," "racism," and "white supremacy." Tragically, many students are easily duped, and they willingly surrender their idealism to a power-hungry movement that resembles a warmed-over leftism from the last century. They are persuaded to be prejudiced in their observations, racist in their conclusions, and bigoted in their defense. Not only are they taught to see through a lens confirming the racism they have been trained to locate, but self-righteousness blinds them to their own movement's racism. Introduced to an abstract construct that makes it unconscionable not to hate their own country's heritage, they are urged to ascribe police shootings of the unarmed that amount to less than one percent of the violent deaths of African Americans annually to an original sin of four centuries ago. ${ }^{3}$ Thus, these students readily swallow an increasingly promoted myth that the achievements of Americans could only be the products of privilege and the oppression of minorities.

Sanctimoniously declaring its commitment to "diversity," academe trains students to be thoughtlessly devoted to ideological conformity. Black students, conditioned to regard white Americans as their oppressors, are taught to seek power by assuming the role of victim and regarding European Americans as inferior-morally inferior. If they reject victimology, they are branded with an ideological cliché like "Uncle Tom.” White students can be redeemed from their racial sins only if they confess and declare themselves "race traitors." To shift guilt from themselves, they charge fellow white Americans-the ones who have avoided academic brainwashing and failed to find social tendencies in American society that merit the terms being applied to them-with being guilty beneficiaries of racial oppression. Operating in an academically contrived world, student recruits of all ethnicities are expected to despise those not privileged enough to attend the elite universities that credential their students for success. Learning to hate someone you don't know, who hasn't done anything to you, and who is outrageous enough not to believe what you believe, is part of a twenty-first century college student's training. Leftist academicians and their propaganda unit, the news media, employ their own "racial profiling" to simplify the identification of enemies. They will have white skin, usually be male. They could be anyone from a Republican to Catholic school kids on a field trip. Or, since the cultural elite is so ravenous for something they can label racist, they could simply be imagined.

3 Heather Mac Donald, The War on Cops: How the New Attack on Law and Order Makes Everyone Less Safe (New York: Encounter Books, 2016), 73-74, 79. 
The irony of educators' consigning a massive group defined by race to a category of racial inferiority even as they demand their students combat racism cannot penetrate the eighth circle of hell once known as academe. Unexamined racist premises lead to gross hypocrisy: the woke reserves for its own use the primitive weapon it accuses others of employing.

The tangible outcome of academic racism - the rotten fruit by which this ideology can legitimately be judged-is rioting, burned buildings, looted stores, bankrupted small businesses, injured police officers, and death. For those who are not ideologically bound, the obvious questions are, "Who is actually hateful?" and "Who inspired them to be so?" But these questions are not answered in classrooms; they cannot even be asked. Moreover, they are suppressed by a mediatariat that has given itself over to what George Orwell called "organized lying." Propagandists of the leftist intelligentsia have dumbed down what were once legitimate concerns about racism to the point where even The View and corporate executives are comfortable jumping on the bandwagon. In Ellul's words, "large numbers of people will support an ideology only if it signifies conformity.” The media have popularized degenerated principles of antiracism, and recruits to the cause are "mesmerized by problems that were formerly true, but presently nonexistent."

Once one escapes the dystopia the academic left has imagined, the assertion that the United States is a racist country can be disproven by abundant contemporary evidence that academic racists cannot afford to consider: the billion and one interactions between American citizens of all races that have nothing to do with inferiority, superiority, racism, or power. In the same country that the woke see darkly, how many citizens of different ethnic groups, sharing a troubled history, nevertheless treat each other with sympathy, kindness, respect, humor, and grace? These incidences are inadmissible because they controvert the left's reductive racial theories. They are a continually developing reality that a decayed ideology cannot account for.

Academic racism is not about remediation of a social problem; it is about discrediting and demoralizing the citizens of a country as a pretext for taking it over. It is a license to discriminate and oppress. It is simply intellectual hatred dressed up as insight and justice. Yeats continues in the poem for his daughter:

Considering that, all hatred driven hence, 
The soul recovers radical innocence

And learns at last that it is self-delighting,

Self-appeasing, self-affrighting,

And that its own sweet will is Heaven's will;

She can, though every face should scowl

And every windy quarter howl

Or every bellows burst, be happy still. ${ }^{4}$

Academic racism is intellectual futility transformed into hatred and power-seeking. But if we teach students the thought of Yeats, Ellul, Orwell, Arendt, and other champions of freedom, we can equip them to detect and reject malicious racial propaganda and discover truthful principles. And one day they can look back and say that academic racism was just academic after all. 